\title{
IFC Environmental \& Social Performance Standards: Soft Law Project \& Company Financing Partnerships towards Good Environmental Governance, Business Sustainability and Sustainable Development in Developing Countries
}

\author{
Edward T. Bristol-Alagbariya \\ Associate Dean \& Senior Multidisciplinary Lecturer, Faculty of Law, University of Port Harcourt, \\ NIGERIA; Affiliate Visiting Fellow, University of Aberdeen, UNITED KINGDOM; and Visiting \\ Research Fellow, Centre for Energy, Petroleum \& Mineral Law and Policy (CEPMLP), Graduate \\ School of Natural Resources Law, Policy \& Management, University of Dundee, Scotland, UNITED \\ KINGDOM \\ * E-mail of the corresponding author: ebristolalagbariya@gmail.com
}

\begin{abstract}
This study is an outcome of a previous work by the author captioned 'Sustainable Development: A Soft Law Concept Transforming SD-Oriented Initiatives of the UN System into Hard Law Instruments in UN Memberstates and Promoting Partnerships around the Globe'. The previous work establishes that there are numerous examples of SD-oriented partnership mechanisms associated with business sustainability, environmental protection, good public sector governance (good governance: GG) and sustainable development (SD), of which the Sustainability Framework of the International Finance Corporation (IFC) is one. The aim of this study is to examine how the IFC's environmental and social (E\&S) performance standards, as key aspects of the corporation's sustainability framework, are being implemented as soft law mechanisms in developing countries (also called developing markets) and emerging economies (also known as emerging markets), where the IFC is engaged in financing, managing developmental projects and corporate financing in various ways. The sustainability framework and its component $E \& S$ standards are international benchmarked standards that have the potential to boost business sustainability and overall SD in developing markets and economies in transition. The study arrives at the finding that the IFC's sustainability framework and the E\&S standards ingrained in it are engineering the E\&S performances of IFC clients engaged in IFC project and corporate financing schemes in developing countries and emerging economies, as well as contributing to business sustainability. These standards are also boosting environmental protection, good environmental governance, corporate social responsibility, social responsibility of host governments and generating SD-oriented partnerships, such as Private Sector Partnerships and Public-Private Sector Partnerships, which contribute to betterment of the welfare of citizens, generic human wellbeing and environmentally-sound and socio-economically equitable growth, prosperity and SD in developing countries. This is particularly so in developing countries where domestic environmental laws, corporate responsibility systems and government social responsibility fall short of the stipulations of the IFC's sustainability framework and its component E\&S performance standards.

Keywords: International Finance Corporation (IFC); Sustainability Framework; Project Financing; Corporate Financing; Developing Countries; Emerging Markets; Environmental and Social Performance (E\&S) Standards; Sustainability Framework; Soft Law; Business Sustainability; Sustainable Development; Good Environmental Governance (GEG); Government Social Responsibility (GSR); Corporate Social Responsibility (CSR); SDoriented Partnerships; Private Sector Partnerships; Public-Private Sector Partnerships (PPSPs); Impact-benefits; Human Wellbeing.
\end{abstract}

DOI: $10.7176 / \mathrm{IAGS} / 81-07$

Publication date:April $30^{\text {th }} 2020$

\section{Introduction}

This study arises from a previous work by the author. ${ }^{1}$ The work proves that the process of implementing SDoriented initiatives of the UN system, various forms of SD-oriented collaborations and partnerships associated with business sustainability and overall sustainable development (SD) are being commutated around the globe. This is particularly so, in developing countries (also called developing markets) and emerging economies (also

\footnotetext{
${ }^{1}$ E. T. Bristol-Alagbariya, 'Sustainable Development: A Soft Law Concept Transforming SD-Oriented Initiatives of the UN System into Hard Law Instruments in UN Member-states and Promoting Partnerships around the Globe [2020] 94 Journal of Law, Policy and Globalization, 40-52.
} 
known as emerging markets and economies in transition). ${ }^{1}$ The work highlights that SD-oriented collaborations ${ }^{2}$ and partnerships being consummated include the UN Global Compact, ${ }^{3}$ the International Finance Corporation (IFC) Sustainability Framework and the Equator Principles (EPs) for EPs designated countries ${ }^{4}$ and EPs compliant banks like the IFC and the Multilateral Investment Guarantee Agency (MIGA). ${ }^{5}$

In the course of the progressive efforts of the $\mathrm{UN}$ on the environment and development, which are aimed at achieving SD, certain UN instruments specify the need and essence of consummating SD-oriented partnerships between and among major UN groups and other stakeholders, such as between and among the Global South-South and Global North-South. ${ }^{6}$ These are partnership instruments emanating from the UN Conference on the Human Environment (UNCHE), held at Stockholm, in 1972 and the UN Conference on Sustainable Development (UNCSD), held in Rio de Janeiro, in 2012 and their progressively ongoing processes. These UN instruments include Paragraphs 1, 6 and 10 of Nairobi Declaration, 1982, on international cooperation to strengthen the protection, management and improvement of the environment; Principle 24 of Stockholm Declaration, 1972, on international cooperation towards the protection and improvement of the environment; Principle 27 of Rio Declaration, 1992, on cooperation and partnership of UN member-states (namely sovereign states of the world) and peoples towards the development of international law in the field of SD; Paragraph 23 of Johannesburg Declaration on SD, 2002, on support for stronger regional groupings and improved international cooperation to promote SD; Paragraph 26 of Johannesburg Declaration on SD, 2002, on continuity of stable partnerships between and among all major groups towards SD, given the long-term perspective of SD; Paragraphs 55, 64, 71, 76 (h), 102, 137, 154, 195, 196, 202, 205, 215, 217, 232, 253, 260 and 280 of the 'Focused Political Outcome Document of the UNCSD (Rio+20), 2012, 'The Future We Want - Outcome

${ }^{1}$ Emerging markets (emerging-market economies) are also known as emerging economies and economies in transition. They refer to low-income and middle-income countries, which have conducted market-oriented economic reforms and are becoming integrated into the global economy. An emerging market is a market that has some characteristics of a developed market (developed or advanced country), but does not fully meet the standards and practices of developed markets. It may be considered as an economy of a developing country (also called a developing market), which is growing and increasingly becoming engaged in global markets, and thus somehow distinct from a typical developing country. There are some characteristic features of emerging markets, which include: (i) lower-than-average per capita income; (ii) high volatility, which may arise from natural disasters, external price shocks and instability of domestic policy; (iii) more susceptibility to volatile currency swings (movements), such as those involving the US dollar, as well as commodity swings, such as those of crude oil or food, as they do not have the political might to influence these movements in their favour; and (iv) potential for growth requiring more investment capital, whereas their capital markets are not advanced as those of advanced markets. As such, investment ricks are more and there is greater reward for investors willing to do and comply with the findings of due diligence before investing in these markets. K. Amadeo, 'Emerging Market Countries and Their Five Defining Characteristics' $<$ https://www.thebalance.com/what-are-emerging-markets3305927>; J. Chappelow and G. Scott (Investopedia), 'Emerging Market Economy' $<$ https://www.investopedia.com/terms/e/emergingmarketeconomy.asp $>$; C. Majaski (Investopedia), 'Developed

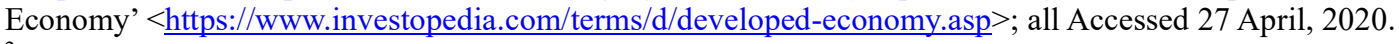

${ }^{2}$ As distinct from collaboration, partnership is considered here to mean a legally binding relationship between two or more parties having specified rights and duties, whereby each party earns certain rewards (as rights) and penalties (as risks for not complying or fulfilling its duties, responsibilities and obligations). However, a collaborative relationship involves cooperation in which parties are not necessarily contractually bound in a legally enforceable manner. Hence, a collaborative relationship is usually considered to be informal as distinct from a legally binding relationship, as it is the case in partnership. Consequently, partnership is superset. Thus, whereas all partnerships involve collaboration, not all collaborative relationships are partnerships. National Coalition for Homeless Veterans, Washington DC, 'Partnership, Collaboration: What is the Difference?'

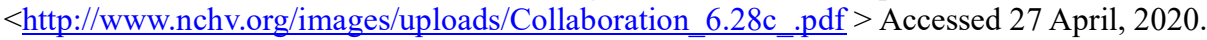

${ }^{3}$ E. T. Bristol-Alagbariya, 'The UN Global Compact as a Soft Law Business Regulatory Mechanism Advancing Corporate Responsibility towards Business Sustainability and Sustainable Development Worldwide' [2020] 94 Journal of Law, Policy and Globalization, 27-39.

${ }^{4}$ Equator principles (EPs) designated countries are countries deemed to have robust environmental and social governance, legislation systems and institutional capacity designed to protect their people and the natural environment. Equator Principles, 'Designated Countries' < $\underline{\text { https://equator-principles.com/designated-countries/> }}$ Accessed 27 April, 2020.

${ }^{5} \mathrm{Ibid}, 48$; homepage of MIGA < https://www.miga.org/> Accessed 27 April, 2020.

${ }^{6}$ UN Department of Economic and Social Affairs, Office for ECOSOC Support and Coordination, Achieving Sustainable Development and Promoting Development Cooperation: Dialogues at the Economic and Social Council (UN 2008). 
Document', on reinvigoration of international cooperation and various forms of partnerships, including global partnerships (of major groups and other stakeholders) towards SD; Chapter 2 of UN Agenda 21, captioned 'International Cooperation to Accelerate Sustainable Development in Developing Countries and Related Domestic Policies'.

It may be highlighted that various UN Conferences on the environment and development, which have, so far, been convened to promote the achievement of SD around the globe are the UNCHE, 1972 (following which the assembly of the world community took place in Nairobi, Kenya, from 10-18 May, 1982, when the UN Nairobi Declaration of 1982 was reached); UN Conference on Environment and Development (UNCED), held at Rio de Janeiro, in 1992; the World Summit on SD (WSSD), held at Johannesburg, in 2002; and the UNCSD, 2012, and the progressively ongoing processes of these conferences. Based on the initials of these conferences, namely 'SRJR', they are called the 'UN SRJR process. In other words, the acronym 'SRJR' refers to the initials of the cities in which these UN Conferences were convened. ${ }^{2}$

Consequently, the aim of this study is to examine how the IFC's environmental and social (S\&E) performance standards are, as integral components of the corporation's sustainability framework, enhancing its projects and corporate financing partnerships, such as Private Sector Partnerships (PSPs) and Public-Private Sector Partnerships (PPSPs), towards advancement of corporate responsibility (corporate social responsibility [CSR]), business sustainability and overall SD in emerging economies and developing countries. Some projects and corporate financing partnerships may be Private Sector Partnerships between the IFC and its clients that are multinational and domestic companies, as well as overall SD, others may be Public-Private Sector Partnerships, which may be Economic Development Agreements (EDAs). ${ }^{3}$ As these partnerships are anchored on the framework of the IFC sustainability framework and its component S\&E performance standards, they promote environmentally-sound and socio-economically equitable growth, prosperity and SD in developing countries and emerging markets.

The study makes a case for strengthening of the IFC's sustainability framework, particularly the E\&S performance standards inherent in the framework, so as to make these standards contribute more to good environmental governance (GEG) and government and corporate social performances, namely government social responsibility (GSR) and CSR, towards greater human wellbeing and SD, in the process of the IFC's projects and corporate financing partnerships in developing countries. Ironically, in such countries, domestic environmental laws, corporate regulatory frameworks and their accompanying corporate responsibility systems and GSR fall short of the stipulations of the IFC's sustainability framework and E\&S performance standards. In relation to the controversial politics of global debt crisis and international and domestic roots of same and the fact that the IFC is one of the four agencies of the World Bank Group vis-à-vis Bretton Woods' institutions established between 1956 and 1988, the study aligns with a critical examination, which considers the IFC's traditional pattern of lending as a factor that contributes to contemporary imperialist international.

\section{The International Finance Corporation}

The International Finance Corporation (IFC), headquartered in Washington DC, United States of America (USA), was established on 20 July, 1956, as an international financial institution that offers investment, advisory and asset-management services to encourage private-sector development in less-developed countries. ${ }^{4}$ The corporation is a sister organisation of the World Bank (The International Bank for Reconstruction and Development (IBRD) and member of the World Bank Group (WBG). The IFC is the largest global development institution that is exclusively focused on business (the private sector) in developing countries. ${ }^{5}$

The IFC applies its financial resources, technical expertise and global experience, which translate into its dynamic and innovative thinking, in order to help its clients and partners around the world overcome financial, operational and other problems and challenges. ${ }^{6}$ The IFC is also a leading mobiliser of third-party resources for projects. It leverages on its products and services, as well as those of other institutions of the WBG, to create

${ }^{1}$ Ibid; E. T. Bristol-Alagbariya (2020 [n1]), 47-48.

${ }^{2}$ E. T. Bristol-Alagbariya (2020 [n1]), 41 and 47-48.

${ }^{3}$ S. I. Pogany, 'Economic Development Agreements' [1992] 7 (1) ICSID Review - Foreign Investment Law Journal, 1-20; Okogbule N. S., Legal Status of Economic Development Agreements (Davis Printing \& Packaging Co. 2004).

4 The Wold Bank Group (WGB), 'About IFC: Overview'

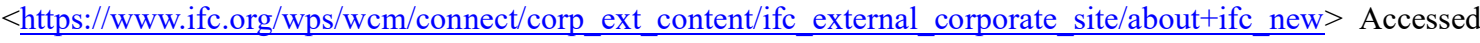
27 April, 2020.

5 IFC (Wold Bank Group [WGB]), 'IFC Insights: About IFC' $<$ https://www.ifc.org/wps/wcm/connect/corp_ext_content/ifc external_corporate site/home $>$ Accessed 27 April, 2020 .

${ }^{6}$ Ibid. 
markets, so as to address development challenges and difficulties across the world. It provides evaluative evidence to help the WBG deliver better services and results to the Bank Group's clients. It does so by examining development effectiveness of the Bank Group and thereby generates lessons from past experiences of the Group towards delivering valuable services to its variety of stakeholders at large. It works with the private sector in developing countries to create markets and thereby opening up opportunities for all in these countries. ${ }^{1}$

The IFC's involvement in project financing and corporate financing in developing countries that are plagued with geopolitical risks and other encumbrances deterring business organisations, enables it to achieve landmark positive development impacts on such countries. Furthermore, the positive impacts of the IFC may be highlighted with regard to its comprehensive approach to private sector development that assists and supports business organisations to innovate and create jobs and other Impact-benefits for people in developing countries, and thereby, along with its clients, helping to impact positively on the lives of people and society around the globe. $^{2}$

Consequently, the IFC believes and operates on the premise which suggests that 'a strong and engaged private sector is indispensable to ending extreme poverty and boosting shared prosperity'. ${ }^{3}$ Also while considering the positive impacts of IFC's clients and partners in terms of improving the lives of people, it is recorded as follows:

Across the world, our investments and advice help the private sector create jobs, improve basic services, foster small enterprises, and more. These stories demonstrate how IFC clients are making a difference in people's lives. ${ }^{4}$

The IFC's plans and policies, which translate into its projects and programmes, are evaluated by the Independent Evaluation Group (IEG). Besides, accountability in the IFC is ensured by its independent Office of the Compliance Advisor Ombudsman (CAO). ${ }^{5}$

The IEG, which is independent of the Management of the WBG and so reports directly to the Executive Board of the WBG, evaluates the development effectiveness of the Bank Group in an integrated manner that covers the World Bank, IFC and Multilateral Investment Guarantee Agency (MIGA), from July $2006 .{ }^{6}$ The Compliance Advisor Ombudsman (CAO), which was established in 1999 and reports directly to the President of the WBG, is the independent accountability mechanism for the IFC and MIGA. The CAO responds to complaints from project-affected communities with the goal of enhancing social and environmental outcomes on the ground.

Apart from IFC and MIGA, the WBG is made up of the International Development Association (IDA) and International Centre for Settlement of Investment Disputes (ICSD). ${ }^{8}$ Together, these are four agencies of World Bank Group (WBG) that were established between 1956 and 1988. Some refer to these agencies as four additional members of the WBG vis-à-vis the historic Bretton Woods' institutions. ${ }^{9}$

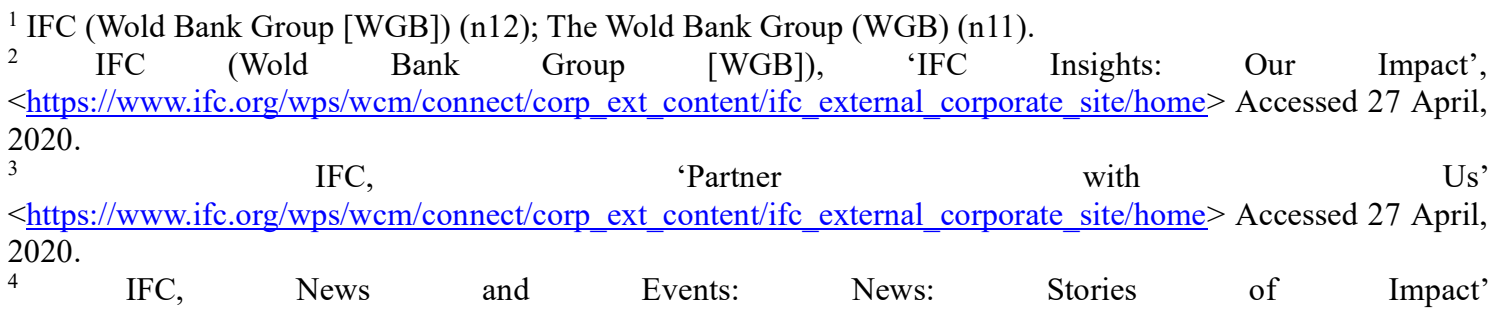
$<$ https://www.ifc.org/wps/wcm/connect/NEWS EXT CONTENT/IFC External_Corporate Site/News+and+Ev ents/News/Impact-Stories > Accessed 27 April, 2020.

${ }^{5}$ The Wold Bank Group (WGB) (n11).

${ }^{6}$ Homepage of the Independent Evaluation Group (IEG) WBG, <https://ieg.worldbankgroup.org/> ; IFC (Wold Bank Group [WGB]), Independent Evaluation Group: Connect with IEG: What We Do, $<$ https://ieg.worldbankgroup.org/> both Accessed 27 April, 2020; WBG, 'Independent Evaluation Group World Bank Project Performance Ratings - $\quad$ Codebook' [September 2015] https://ieg.worldbankgroup.org/sites/default/files/Data/reports/ieg-wb-project-performance-ratingscodebook 092015.pdf $>$ all Accessed 27 April, 2020.

${ }^{7}$ Compliance Advisor Ombudsman, 'Our Mandate' < http://www.cao-ombudsman.org/>; Compliance Advisor Ombudsman, 'About the CAO: Who We Are' < http://www.cao-ombudsman.org/about/whoweare/index.html $>$ both Accessed 27 April, 2020.

8 Homepage of the International Centre for Settlement of Investment Disputes (ICSD), $<$ https://icsid.worldbank.org/en/> Accessed 27 April, 2020.

9 K. M. E. Dominguez, 'International Finance and the Bretton Woods Institutions' [November 2006] International Political Economy (IPE) Workshop on International Policy (slide no. 22), <http://wwwpersonal.umich.edu/ kathrynd/BrettonWoodsandInternationalFinance.pdf $>$ Accessed 27 April, 2020. 


\section{IFC's Approach to Sustainability}

It may be cogent to briefly consider the term 'sustainability', as well as give a little attention to the subject-matter of 'sustainability' in relation to 'sustainable development' before proceeding to discuss the approach of IFC to sustainability.

\subsection{Sustainability}

Briefly and simply put, sustainability suggests the ability to maintain a certain indicated or required rate or level. It means avoidance of the depletion of overall resources of nature, so as to maintain an ecological balance between and among all natural resources, in the best and overall interest and wellbeing of humans and the resources of nature in society and the entire Planet Earth. In other words, sustainability means the possibility of the wellbeing of humans and overall resources of nature to continue in an uninterrupted manner, over a period of time, often foreseeable human time scale, by causing little or without causing any damage to the environment and its supporting ecological base, ecosystem and eco-system services on the Planet Earth. ${ }^{1}$ Some thus consider sustainability in the context of economic growth, advancement and prosperity, as well as in relation to global ecological base and environmental sustainability. Sustainability is considered in the context of the degree of wellbeing of humans and natural resources in relation to the carrying capacity of the Earth's ecological base, eco-systems and eco-system services. Sustainability thus involves the wellbeing of humans and other natural resources in context of the wellbeing of the environment, as well as sustained economic development and overall advancement of society in a manner that generates economic wellbeing and prosperity in a socially-equitable (just) manner. The theory of sustainability thus describes a form of economy and society that is lasting and can be lived on a global scale. It connotes society's potential for fair play between and among generations, and more global justice within, between and among countries and then society at large on Planet Earth. Thus, the movement towards sustainability, regarding how to achieve a more just, sustainable and peaceful world on the platform and strength of the wellbeing of humans and overall resources of nature, to enable the Earth thrive, is an age-old movement. ${ }^{2}$

\subsection{Sustainability and Sustainable Development}

Sustainability may be more concretely considered in relation to SD, as evidenced by ongoing global efforts and trend toward SD, progressively being spearheaded by the UN. SD and sustainability are thus associated with the twin relationship between the environment and development. ${ }^{3}$

Sustainability suggests a state of continuing and stable human wellbeing, in consonance with the allinclusive wellbeing of other forms of nature (overall nature) on Planet Earth. Such a state may be considered to be an excellent one, characterised by stable wellbeing of overall nature on Planet Earth. It is a state of society that is characterised by stable and sustainable nature, wherein environmental and development plans, policies and programmes (including projects [PPP]), harmoniously align with each other. It is also a state of society, which is organised harmoniously with the environment and overall nature, in a manner that does not hinder, degrade, destroy and despoil the environment, ecology, ecosystem and ecosystem services, so as not to threaten the ecological base of society and the Plant Earth at large. ${ }^{4}$ It is a state of society and human civilisation where or

1 Cambridge Dictionary, 'Sustainability' <https://dictionary.cambridge.org/dictionary/english/sustainability $>$ Accessed 27 April, 2020.

${ }^{2}$ Homepage of the Earth Charter Initiative <http://earthcharter.org/>; F. Ekardt (Research Unit Sustainability and Climate Policy), 'Theory of Sustainability' $<\underline{\text { http://www.sustainability-justice- }}$ climate.eu/en/nachhaltigkeit.html >; $\quad$ W. Jenkins, $\quad$ Sustainability $<$ https://www.berkshirepublishing.com/assets_news/sustainability/Spirit_SustainabilityTheory.pdf $>$; University of Alberta, Office of 'What is Sustainability? $<$ https://www.mcgill.ca/sustainability/files/sustainability/what-is-sustainability.pdf $>$ all Accessed 27 April, 2020.

3 The World Commission on Environment and Development (WCED), Our Common Future (Oxford University Press 1987), especially 37-41 and 65; Principle 3, Stockholm Declaration on the Human Environment, 1972; E. T. Bristol-Alagbariya, 'Theories and the Legal Principle of Permanent Sovereignty over Natural Wealth and Resources in Relation to Petroleum Development in Nigeria' [2019] 4 (2) University of Port Harcourt Journal of Private Law, 204-206; E. T. Bristol-Alagbariya, Governance Towards Sustainable Development in Nigeria: The Role of Strategic Assessment of Decisions \& Actions (Centre for Energy, Petroleum \& Mineral Law \& Policy [CEPMLP]/Dundee University Press [DUP] 2013) 33-35.

${ }^{4}$ United Nations Environment Programme (UNEP), Healthy Environment, Healthy People (UNEP 2016); Goal 3, UN SDGs, captioned 'Good Health and Wellbeing'; The WCED, Our Common Future (Oxford University Press 1987), 37-41 and 65, which explains that when people put the environment first, development will last; Principle 3, Stockholm Declaration on the Human Environment, 1972, which states as follows: Man has constantly to sum up experience and go on discovering, inventing, creating and advancing. In our time, man's 
when humans exist harmoniously with other forms or species of nature on Planet Earth. Such a state of society may be considered a perfect or near-perfect state, which is a far more utopian state than SD. Such an ecoefficient and eco-effective society is certainly utopian society in the history of humanity and world civilisation. ${ }^{1}$

Sustainability may be considered in the context of and in relation to SD, given that it is a far more utopian and more difficult state of human existence and the existence of society that is more utopian to achieve than $\mathrm{SD}$, as sustainability requires more radical changes than $\mathrm{SD} .^{2}$

$\mathrm{SD}$ is a pathway to a safer, harmonious, equitable, greener and more prosperous world for all humans, other resources of nature and society at large on Planet Earth. ${ }^{3}$ The World Commission on Environment and Development (WCED), otherwise known as the Brundtland Commission, in its landmark and celebrated report entitled Our Common Future, defines SD as the development which meets the needs of the present without compromising the ability of future generations to meet their own needs. ${ }^{4}$ Humanity and society at large are in the age of SD. ${ }^{5}$ SD embedded in the concept of sustainability is the foundation for contemporary humanity's ongoing and leading global framework for international cooperation and partnerships around the world. ${ }^{6}$

capability to transform his surroundings, if used wisely, can bring to all peoples the benefits of development and the opportunity to enhance the quality of life. Wrongly or heedlessly applied, the same power can do incalculable harm to human beings and the human environment. We see around us growing evidence of man-made harm in many regions of the earth: dangerous levels of pollution in water, air, earth and living beings; major and undesirable disturbances to the ecological balance of the biosphere; destruction and depletion of irreplaceable resources; and gross deficiencies, harmful to the physical, mental and social health of man, in the man-made environment, particularly in the living and working environment.

${ }^{1}$ E. T. Bristol-Alagbariya (2019 [n25]), 204-206.

2 Ibid; M. Burton, 'Sustainability: Utopian and Scientific' < $<$ http://links.org.au/node/1198> Accessed 13 October, 2019; M. de Freitas, 'Sustainability: The Utopia of Utopias' $<$ https://globaljournals.org/GJHSS Volume15/3Sustainability-The-Utopia.pdf $>$ Accessed 13 October, 2019; E. Doronzo, 'Economic and Environmental Sustainability: Utopia or Reality?' $<$ http://socisdg.com/en/blog/economic-and-environmental-sustainabilityutopia-or-reality/> all Accessed 27 April, 2020; A. Gare, 'From 'Sustainable Development' to 'Ecological Civilization': Winning The War for Survival' [2017] 13 (3) Cosmos and History: The Journal of Natural and Social Philosophy, 130-153.

${ }^{3}$ Homepage of the Earth Charter Initiative (n24); D. Pijawka and B. Hagen, Sustainability for the 21st Century: Pathways, Programs, and Policies (Kendall Hunt Publishing 2018); K. B. Lindahl et al, 'Theorising Pathways to Sustainability' [2016] 23 (5) International Journal of Sustainable Development \& World Ecology, 399-411; Utrecht University, 'Pathways to Sustainability' < https://www.uu.nl/en/research/sustainability>; International Science Council, 'Transformations to Sustainability: Transformative pathways to sustainability: learning across disciplines, contexts and cultures' $<$ https://ransformationstosustainability.org/research/pathways/>; both Accessed 27 April, 2020; Principle 1 of Rio Declaration on Environment and Development, 1992, which provides that human beings are at the centre of concerns for sustainable development. They are entitled to a healthy and productive life in harmony with nature.

${ }^{4}$ WCED, Our Common Future (Oxford University Press 1987), 8, 40 and 43.

5 J. F. Sachs, The Age of Sustainable Development (University of Columbia Press 2015); United Nations General Assembly, 'Resolution adopted by the General Assembly on 25 September 2015 70/1: Transforming Our World: the 2030 Agenda for $\quad$ Sustainable Development' $<$ https://www.un.org/en/development/desa/population/migration/generalassembly/docs/globalcompact/A RES 7 0 1_E.pdf $>$ Accessed 27 April, 2020.

6 International Institute for Sustainable Development (IISD), 'Sustainable Development' < $<$ https://www.iisd.org/topic/sustainable-development>; UN SD Goals Knowledge Platform 'Sustainable Development Goals' <https://sustainabledevelopment.un.org/?menu=1300>; both Accessed 27 April, 2020; Goal 17: UN Sustainable Development Goals (SDGs) (UNSDGs), captioned 'Partnerships for the Goals', which is designed to strengthen the means of implementation and revitalise the global partnership for SD; UN Economic and Social Council (ECOSOC), which brings people and issues together to promote collective action for a sustainable world. ECOSOC is a platform for fostering debate and innovative thinking, coordinates, through intergovernmental bodies, follow-up measures of major UN conferences and summits, such as organising UN member-states to translate internationally agreed SD initiatives, like those on partnerships towards SD, into actual programmes in the member-states; homepage of ECOSOC $<$ https://www.un.org/ecosoc/en/> UN ECOSOC, 'About ECOSOC: ECOSOC at a Glance' $<$ https://www.un.org/en/ecosoc/about/>; UN ECOSOC, 'ECOSOC: About Us' $<$ https://www.un.org/ecosoc/en/about-us $>$ all Accessed 27 April, 2020; UN Department of Economic and Social Affairs, Office for ECOSOC Support and Coordination (n7). 


\subsection{Business Sustainability and the IFC}

So far, from the foregoing sub-heading, we have seen that SD is a pathway to sustainability, and that humanity and society at large are in the age of SD. It may also be emphasised that the subject-matter of sustainability, which is associated with business (business organisations: companies) in the form of business sustainability, is important and critical to the success of business. ${ }^{1}$

Consequently, in the ongoing era of SD, it is significant to note that the success of business is determined by its shareholders as well as its variety of stakeholders, ${ }^{2}$ such as staff-strength, customers, directly affected citizens and citizen-groups like communities, the environment and broader stakeholders outside the operational areas of business, but within the value chain of business organisations. ${ }^{3}$

Concerning variety of stakeholders of business, whereas some stakeholders are directly and dominantly affected by the operations of business, others are not so directly and mainly impacted and thus not predominantly concerned about the operations of business; nevertheless, the latter category are also stakeholders affected by the value chain (albeit distant value chain) of the operations of business. For example, whereas the oil-bearing (producing) communities in Nigeria may be dominantly affected by the adverse impacts of the operations of a hypothetical multinational oil producing company ('MNOCN'), ${ }^{4}$ distant consumers of Nigeria's crude oil, such as consumer-nations like India and China, as well as consumers within India and China, may not be directly and mainly be affected by the operations of 'MNOCN' (the multinational oil producing company in Nigeria).

Essentially, the issue of business sustainability brings to the fore, the growing stakeholder perspective and recognition of the stakeholder thinking in business relations. This is specifically so concerning energy and major natural resources extractive industrial operations (EIOs), which impact negatively on the environment and SD. Generally, EIOs, such as oil and gas and other mineral resources development operations, taking place in developing countries - particularly resources-rich developing countries suffering from the resource curse,$-{ }^{5}$

${ }^{1}$ M. Blowfield, Business and Sustainability (Oxford University Press 2013); P. E. Wells, Business Models for Sustainability (Edward Elgar Publishing 2013); W. Visser, The Top 50 Sustainability Books (Greenleaf Publishing 2009); D. Hitchcock and M. Willard, The Business Guide to Sustainability: Practical Strategies and Tools for Organizations (Earthscan 2009); M. H. Posner, 'Michael H. Posner: Why It Pays for Businesses to Boost Sustainability' <https://www.ge.com/reports/post/96692402429/why-it-pays-for-businesses-to-boostsustainability/> Accessed 27 April, 2020.

${ }^{2}$ R. E. Freeman, Strategic Management: A Stakeholder Approach (Cambridge University Press 2013); J. F. Johnston, No Man Can Serve Two Masters: Shareholders versus Stakeholders in the Governance of Companies (The Social Affairs Unit 1998); A. L. Friedman and S. Miles, Stakeholders: Theory and Practice (Oxford University Press 2006); J. S. Andiof et al (eds), Unfolding Stakeholder Thinking: Theory, Responsibility and Engagement (Routledge 2017); J. S. Andiof et al (eds), Unfolding Stakeholder Thinking 2: Relationships, Communication, Reporting and Performance (Routledge 2017); K. Omeje, High Stakes and Stakeholders: Oil Conflict and Security in Nigeria (Routledge 2016).

${ }^{3}$ T. McGuffog, Building Effective Value Chains: Value and its Management (Kogan Page 2016); M. D'heur (ed), Sustainable Value Chain Management: Delivering Sustainability Through the Core Business (Springer International Publishing 2015); Cambridge Institute for Sustainability Leadership, 'What is a Value Chain? Definitions and Characteristics' $<$ https://www.cisl.cam.ac.uk/education/graduate-study/pgcerts/value-chaindefs $>$; European Commission, 'Agriresearch Factsheet: Sustainable, Circular and Innovative Value Chains' <file:///C:/Users/Edward/Downloads/AGRI Factsheets 10 Value-Chains OKpdf.pdf > Accessed 27 April, 2020.

${ }^{4} \mathrm{~K}$. Omeje (ed), Extractive Economies and Conflicts in the Global South: Multi-Regional Perspectives on Rentier Politics (Ashgate Publishing 2008); D. S. Olawuyi, Extractives Industry Law in Africa (Springer Nature Switzerland AG 2018); P. D. Cameron and M. C. Michael, Oil, Gas, and Mining: A Sourcebook for Understanding the Extractive Industries (World Bank Group 2017); M. T. Ladan, Sustainable Development Goals, Climate Change and Extractive Resource Management in Africa (Ahmadu Bello University Press 2017); K. Omeje (2016 [n34]).

${ }^{5}$ P. J. Stevens, 'The Resource Curse Revisited Appendix: A Literature Review' [2015] The Royal Institute of International Affairs, 1-42; F. van der Ploeg, 'Natural Resources: Curse Or Blessing?' [2011] 49 (2) Journal of Economic Literature, 366-420; E. T. Bristol-Alagbariya, Petroleum Development \& the Environment in Rivers State Nigeria: Fallouts of the UNEP Report on Ogoniland, Environmental Regulatory Standards \& Sustainable Development Laws \& Practices (LAP LAMBERT Academic Publishing 2018), 39; E. T. Bristol-Alagbariya, Participation in Petroleum Development: Towards Sustainable Community Development in the Niger Delta (CEPMLP/DUP 2010), 49, 75, 147 and 318; E. T. Bristol-Alagbariya, 'The Concept, Principle, Law and Developmental Practice of Environmental Democracy towards Sustainable Development in Resources-rich Communities of Developing Countries: Focus on Nigeria's Oil Producing Delta Region' [2020] 94 Journal of Law, Policy and Globalization, 53, 55, 61-62, 66 and 69; J. Rexler, 'Beyond the Oil Curse: Shell, State Power, and Environmental Regulation in the Niger Delta' [2010] 12 (1) Stanford Journal of International Relations, 26- 
characteristically impact negatively on the environment and inhibit SD. These operations are however advantageous when they are implemented well so as to preserve the rights of people who are directly affected by them, and if the benefits they generate are well-used. On the whole, over and again, landmark studies, which are being substantiated by case-studies of ongoing extractive industrial (EI) projects in resources-rich developing countries, are consistently proving that if EIOs are properly governed in conformity with international benchmarked norms, values and practices, these operations can contribute to poverty reduction and environmentally-sound and socio-economically equitable SD. ${ }^{1}$ Such monumental studies include the Minerals and Sustainable Development (MMSD) project $^{2}$ and the WBG Extractive Industries Review (EIR). ${ }^{3}$

The IFC's approach to sustainability is governed by the corporation's sustainability framework and corporate governance methodology, which are designed to help its clients (as business organisations) to improve their performances, enhance transparency, engage with the people affected by the projects financed by the IFC, protect the environment and achieve other development Impact-benefits. ${ }^{4}$ The IFC's sustainability framework is an integral part of the corporation's approach to risk management and its strategic commitment to SD. The IFC uses its sustainability framework along with other strategies, policies and initiatives to direct its business activities, in order to achieve its overall development objectives. The framework has two components, namely the corporation's policy and performance standards on E\&S sustainability ${ }^{5}$ and its access to information policy. ${ }^{6}$

The IFC's policy on E\&S sustainability describes the corporation's commitments, roles and responsibilities towards E\&S sustainability. The corporation's performance standards on E\&S are directed towards its clients, so as to provide guidance on how they can identify risks and other adverse impacts. These standards are designed to commit the corporation's clients to embark on information disclosure and engagement of their stakeholders, as well as to help them avoid, mitigate and manage risks and other negative impacts of the projects associated with them. The IFC's access to information policy reflects IFC's commitment to transparency and good governance on its operations and outlines the corporation's institutional disclosure obligations regarding its investment and advisory services. ${ }^{7}$

The IFC helps its clients to understand and manage the environmental, social and corporate governance (ESG) risks they face. The corporation partners with the private sector, such as businesses and its other stakeholders in developing countries and regions, in order to find innovative solutions that create opportunities for economically, socially and environmentally sustainable private sector investments, which are capable of contributing to increased employment opportunities and generic public good, such as social equity, all-inclusive growth and prosperity in the domestic jurisdiction of projects and companies financed by the corporation. IFC's ESG policies, guidelines and tools are widely adopted as market standards and embedded in operational policies by corporations, investors, financial intermediaries, stock exchanges, regulators and countries in which the IFC

31; Principle 3, UN Stockholm Declaration on the Human Environment, 1972.

${ }^{1}$ E. T. Bristol-Alagbariya (2010 [n37]), 83-101, especially 100; E. T. Bristol-Alagbariya, 'Environmental Assessment Law and Practice in Nigeria towards Achieving the UN Sustainable Development Goals (UNSDGs) in the Country: Cases of SDGs 13 and 17' [2019] 92 Journal of Law, Policy and Globalization, 75-76; E. T. Bristol-Alagbariya, 'The Concept, Principle, Law and Developmental Practice of Environmental Democracy towards Sustainable Development in Resources-rich Communities of Developing Countries: Focus on Nigeria's Oil Producing Delta Region' [2020] 94 Journal of Law, Policy and Globalization, 53, 62 and 69-70.

${ }^{2}$ International Institute for Environment and Development (IIED) and World Business Council for Sustainable Development (WBCSD), Breaking New Ground: Mining, Minerals, and Sustainable Development: The Report of the MMSD Project (Earthscan 2002).

${ }^{3}$ World Bank Group, 'Striking a Better Balance - The World Bank Group and Extractive Industries: The Final Report of the Extractive Industries Review, World Bank Group Management Response' $<$ http://documents.worldbank.org/curated/en/961241468781797388/pdf/300010GLB.pdf $>$ Accessed 27 March, 2020; D. S. Olawuyi (n36); P. D. Cameron and M. C. Michael (n36).

4 IFC, 'IFC Insights: IFC Sustainability

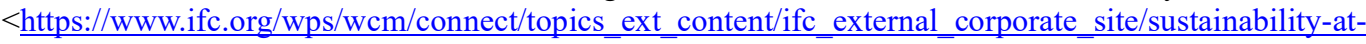
ifc/policies-standards/sustainability+framework $>$ Accessed 27 March, 2020.

5 IFC, 'IFC Insights: Environmental and Social Sustainability Policy' $<$ https://www.ifc.org/wps/wcm/connect/topics ext content/ifc external corporate site/sustainability-atifc/policies-standards/sustainability-policy/sustainability-policy> Accessed 27 March, 2020.

6 IFC, 'IFC Project Information \& Data Portal: Access to Information Policy (AIP)' $<$ https://disclosures.ifc.org/\#/accessInfoPolicy > Accessed 27 March, 2020; IFC, IFC Sustainability Framework: Policy and Performance Standards on Environmental and Social Sustainability Access to Information Policy Effective January 1, 2012 (IFC 2012), 55-67.

${ }^{7}$ IFC, 'IFC Insights: IFC Sustainability Framework' (n41). 
is financing projects. ${ }^{1}$ These policies, guidelines and tools help investors and other partners associated with the corporation's projects to earn financial returns for their investments, as well as enable them achieve positive impacts in the interest of society, particularly where such investment projects are taking place. ${ }^{2}$ Also, these policies help markets, which include developing markets and emerging markets ${ }^{3}$ to improve on their ESG standards and maintain a level playing field to enhance public good, particularly overall public interest. By and large, regarding the IFC's direct investments and the corporation's project finance and corporate finance schemes organised through financial intermediaries, the IFC requires that its clients and partners should apply these performance standards to manage E\&S risks and other adverse impacts, so as to enhance Impact-benefits of its development opportunities around the world. The IFC's performance standards on E\&S sustainability may also be applied by other financial institutions. ${ }^{4}$

Therefore, it could be argued that the IFC's sustainability framework gave rise to the corporation's peculiar policies and standards. Among these policies and standards are the corporation's E\&S performance standards, which are globally recognised as benchmarked standards for managing environmental and social risks of private sector (business) operations, such as the IFC's projects financing and corporate financing schemes. ${ }^{5}$

\section{The IFC's Environmental and Social (E\&S) Performance Standards}

It has already been stated that the IFC uses the sustainability framework along with other strategies, policies, and initiatives to direct its business activities, so as to achieve its overall development objectives. The 2012 edition of IFC's sustainability framework, which contains the performance standards, applies to all investment and advisory clients whose projects go through IFC's initial credit review process after January 1, $2012 .^{6}$ Together, there are eight performance standards that IFC's clients are to comply with throughout the life of an investment associated with the IFC. ${ }^{7}$ They are namely (i) Performance Standard 1 (on Assessment and Management of Environmental and Social [E\&S] Risks and Impacts) $;^{8}$ (ii) Performance Standard 2 (on Labour and Working Conditions) $;{ }^{9}$ (iii) Performance Standard 3 (on Resource Efficiency and Pollution Prevention) ${ }^{10}$ (iv) Performance Standard 4 (on Community Health, Safety, and Security); ${ }^{11}$ (v) Performance Standard 5 (on Land Acquisition and Involuntary Resettlement [including Economic Displacements]); ${ }^{12}$ (vi) Performance Standard 6 (on Biodiversity Conservation and Sustainable Management of Living Natural Resources); ${ }^{13}$ (vii) Performance Standard 7 (on Indigenous Peoples [including Aboriginal Groups]; ${ }^{14}$ and (viii) Performance Standard 8 (Cultural Heritage). ${ }^{15}$

\section{${ }^{1}$ Ibid.}

${ }^{2}$ Ibid.

${ }^{3}$ K. Amadeo (n2); J. Chappelow and G. Scott (Investopedia) (n2); C. Majaski (Investopedia) (n2); J. Hölscher and H. Tomann (eds), Palgrave Dictionary of Emerging Markets and Transition Economics: Insights from Archival Research (Palgrave Macmillan 2015); M. Mobius, The Little Book of Emerging Markets: How to Make Money in the World's Fastest Growing Markets (John Wiley \& Sons 2012); L. E. Pereiro, Emerging Markets: A Practical Approach (John Wiley \& Sons 2002); M. Mobius, Mobius on Emerging Markets: The Investor's Guide to Emerging Markets (Pitman Publishing 1996).

4 IFC, 'IFC Insights: Environmental and Social Sustainability Policy' $<$ https://www.ifc.org/wps/wcm/connect/topics ext content/ifc external corporate site/sustainability-atifc/policies-standards/sustainability-policy/sustainability-policy> Accessed 27 April, 2020.

${ }^{5}$ IFC, 'IFC Insights: IFC Sustainability Framework' (n41).

6 IFC, IFC Insights: IFC Sustainability Framework - 2012 Edition $<$ https://www.ifc.org/wps/wcm/connect/topics ext content/ifc external corporate site/sustainability-atifc/policies-standards/ifcsustainabilityframework_2012>; IFC, IFC Insights: IFC Sustainability Framework Effective January $1, \quad 2012 \quad<$ https://www.ifc.org/wps/wcm/connect/ea072259-f715-4971-a92090c0ca90bc95/IFC Sustainability \%2BFramework.pdf?MOD=AJPERES\&CVID=kTjZB1i > both Accessed 27 April, 2020; IFC, IFC Sustainability Framework: Policy and Performance Standards on Environmental and Social Sustainability Access to Information Policy Effective January 1, 2012 (IFC 2012).

${ }^{7}$ IFC, IFC Sustainability Framework: Policy and Performance Standards on Environmental and Social Sustainability Access to Information Policy Effective January 1, 2012 (n50).

${ }^{8}$ Ibid, 16-23.

${ }^{9}$ Ibid, 24-28.

${ }^{10}$ Ibid, 29-32.

${ }^{11}$ Ibid, 33-35.

${ }^{12}$ Ibid, 36-41.

${ }^{13} \mathrm{Ibid}, 42-46$.

${ }^{14}$ Ibid, 47-51.

${ }^{15}$ Ibid, 52-54. 


\section{IFC Soft Law Partnership Arrangements in the Process of Implementing the Corporation's Performance Standards in Developing Countries}

It has already been stated that IFC's sustainability framework, which gave rise to the IFC's peculiar policies and standards that include its E\&S performance standards, is an international benchmarked sustainability framework. It has also been mentioned that the corporation's E\&S performance standards are international benchmarked standards, which the corporation implements in the process of financing projects and corporate financing, so as to identify and manage risks, especially E\&S risks associated with its projects financing and corporate financing schemes in developing countries. Given that these IFC's standards are international regulatory standards, they are soft law instruments or mechanisms, implemented in the domestic jurisdictions of developing countries in the course of project financing and corporate financing associated with the IFC.

Briefly put, the term 'soft law', which is being enthusiastically and emotionally debated by scholars of the legal profession and law-related multidisciplinary scholars around the globe, denotes a worldwide variety of international legal and regulatory instruments, which have persuasive effects in the domestic jurisdictions of sovereign states. ${ }^{1}$ Soft law mechanisms are thus not out rightly (legally) binding in the domestic spheres of sovereign states, except and/or until when any of such mechanisms is specifically incorporated and adopted into the legal system of these states. ${ }^{2}$ The exceptions here are soft law mechanisms that are applied in the domestic jurisdictions of sovereign by virtue of state practice, which are not backed by specific domestic laws or domestic legislative instruments, such as regulations, guidelines and standards. These include the ten principles of the UN Global Compact ${ }^{3}$ and the IFC's sustainability framework and this framework's E\&S performance standards, which are applied by virtue of PSPs and PPSPs that are consummated between the IFC and its clients and intermediaries, including host governments, in the course of the IFC's project and corporate financing schemes in developing countries and emerging economies. Other examples of soft law are UN General Assembly [UNGA] declarations, recommendations and resolutions, treaties, as well as voluntary resolutions, recommendations, policies, principles, codes of conduct, guidelines, norms and standards, which emanate from the international sphere like those of the above-stated UN Global Compact and the IFC's E\&S performance standards, which constitute the subject-matter of this study. Thus, although soft law instruments and mechanisms are modes of conduct, which govern or regulate the humans, business (the private sector), government and overall society in the domestic jurisdiction of a sovereign state, they are distinct from hard laws (of sovereign states). Soft law mechanisms may be distinguished from hard laws (especially positive law [legal positivist] instruments), which are obligatory modes of conduct that are outrightly binding on its component parties to them and can thus be promptly and legally enforced against any of the parties. Often hard laws govern humans and society at large, within domestic jurisdictions of sovereign states, as distinct from soft laws, which emanate from and mainly exist within international spheres or the entire global arena. In the course of ongoing efforts of the UN and other related international follow-up endeavours (such as those of the global extractive industrial sector) on the environment and development so as to achieve SD, benchmarked soft law regulatory mechanisms are increasingly evolving to govern SD-oriented and sustainability issues in sovereign states, particularly in developing countries. ${ }^{4}$

\subsection{Implementing the IFC's Environmental and Social (E\&S) Performance Standards}

To implement its Environmental and Social Performance Standards, the IFC enters into partnerships in the course of its investments in economies in transition and developing countries, where these investments take place. While implementing these standards in the course of financing projects and corporate financing, the IFC

${ }^{1}$ A. T. Guzman and T. L. Meyer, 'International Soft Law' [2010] 2 (1) The Journal of Legal Analysis, 171-225; J. B. Skjærseth et al, 'Soft Law, Hard Law, and Effective Implementation of International Environmental Norms' [2006] 6 (3) Global Environmental Politics, 104-120; U. Etemire, 'Reflections on the Role of International Custom and Soft Law in Environmental Protection' [2016] 1 (1) UNIPORT Journal of Public Law, 60-61; E. T. Bristol-Alagbariya, 'Duties Inherent in Permanent Sovereignty over Natural Wealth and Resources: A Case for Domestication of Benchmarked Regulatory Standards and Practices Governing Petroleum Development in Nigeria' (2019) 11 (1) Journal of Property Law and Contemporary Issues, 134, 138 and 152.

2 Section 12, 1999 Constitution of the Federal Republic of Nigeria (CFRN) (as amended), captioned 'Implementation of Treaties'.

${ }^{3}$ Homepage of the UN Global Compact $<$ https://www.unglobalcompact.org/>; UN Global Compact, "Who are We: Business as a force for good' $<$ https://www.unglobalcompact.org/what-is-gc/mission $>$; UN Global Compact, 'The Power of Principles: The Ten Principles of the UN Global Compact' $<$ https://www.unglobalcompact.org/what-is-gc/mission/principles $>$ all on Accessed 27 April, 2020.

${ }^{4}$ E. T. Bristol-Alagbariy (2019 [n60]), 138. 
enters into partnership arrangements with its private sector clients (which include its projects advisory and corporate finance advisory clients) and third parties associated with its investments (financing schemes) in economies in transition and developing countries. In the process, among other partnership arrangements, the IFC enters into Public Private-Partnerships. ${ }^{1}$ On this note, the corporation states as follows:

Public-private partnerships (PPPS) are tools that help governments leverage the expertise and efficiency of the private sector, raise capital, and spur development. They also help allocate risk across the public and private sectors to where it can best be managed and ensure that resources are wisely distributed in addressing the most urgent development needs.

IFC's advice in PPPs is helping national and municipal governments in developing countries partner with the private sector to improve access to education, energy, transport, healthcare and sanitation. ${ }^{2}$

Also, MIGA provides political risk insurance (guarantees) for projects in a broad range of sectors in developing member-countries, covering all regions of the world. MIGA guarantees offer much more than just the assurance that losses will be recovered. The insurance of MIGA benefits investors and lenders. MIGA could guarantee the IFC's projects and services in certain ways. Firstly, in terms of providing environmental and social expertise, MIGA helps investors and lenders ensure that projects comply with what are considered to be the world's best social and environmental safeguards. ${ }^{3}$ Secondly, concerning deterring harmful actions, MIGA's status as a member of the World Bank Group and its relationship with shareholder-governments provides additional leverage in protecting investments. ${ }^{4}$ Thirdly, on dispute resolution, MIGA, as an honest broker, intervenes at the first sign of trouble to resolve potential investment disputes before they reach claim status, helping to maintain investments and keep revenues flowing. If MIGA is unable to prevent a claim, our strong balance sheet allows us to make prompt payments. ${ }^{5}$ Fourthly, regarding access to funds, MIGA guarantees can help investors obtain project finance from banks and equity partners. Fifthly, with regard to increasing tenors, MIGA can provide insurance coverage for up to 15 years (in some cases 20), which may increase the tenor of loans available to investors. ${ }^{6}$ To provide extensive country knowledge, MIGA applies decades of experience, global reach and knowledge of developing countries to each transaction. Sixthly, concerning lowering borrowing costs, MIGA-guaranteed loans may help reduce risk-capital ratings of projects. $^{7}$

MIGA also strives to achieve the foregoing by entering into partnership with IFC clients, in the course of the corporation's investments, be they project financing or corporate financing.

Considering that the IFC's E\&S performance standards apply as soft law mechanisms in developing countries, in order to implement these standards on private sector organisations in these countries, these organisations enter into partnership with the IFC or its agents in the countries. On this note IFC states as follows:

... we are building internal capacity and have developed a number of implementation tools to both facilitate and monitor the implementation of the standards and to assist companies in meeting them.

... Sustainability ... comprises all aspects of a successful business: financial, economic, environmental, social as well as governance issues. Strengthening good corporate governance in our client companies is an essential role for IFC. Combating corruption is an essential role for the whole World Bank Group. ${ }^{8}$

IFC further states that it is committed 'to promote sustainable private sector investment in developing countries', and thereby helps to 'reduce poverty and improve people's lives' in these countries. ${ }^{9}$ By so doing, the IFC's E\&S performance standards have the potential to improve PPPs as well as laws, regulations, institutional mechanisms and state-practice in developing countries, where there are gaps that are below the benchmarked policies and standards of the IFC. The implementation of the IFC's E\&S performance standards may thus be described as a way of entering into projects-related finance and corporate finance partnership arrangements towards the sustainability of IFC's business (business sustainability) and overall SD by contributing to make

$1 \quad$ IFC, Public Private-Partnerships: Overview' $<$ https://www.ifc.org/wps/wcm/connect/Industry EXT Content/IFC External Corporate Site/PPP $>$ Accessed 27 April, 2020.

${ }^{2}$ Ibid.

${ }^{3}$ MIGA, What We Do: Learn About Our Process'<https://www.miga.org/what-we-do $>$ Accessed 27 April, 2020.

${ }^{4}$ Ibid.

5 Ibid.

${ }^{6}$ Ibid.

${ }^{7}$ Ibid.

$8 \quad$ IFC, $50 \quad$ Years: Choices Matter $2005 \quad$ Sustainability Report'

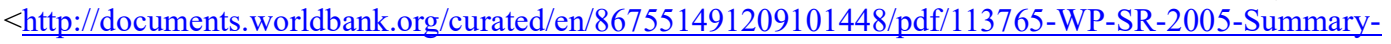
English-PUBLIC.pdf $>$ Accessed 27 April, 2020.

${ }^{9}$ Ibid. 
projects impact positively on the lives of people and society at large in these countries, including economies interactions. The IFC may thus engage in project finance, in such areas as infrastructure, healthcare, education, transport, sanitation, energy and natural resources EIOs, directly with its clients, as well as between it and third parties, through MIGA, in a manner that could contribute to sustainable development in developing countries.

In developing countries like Nigeria, the IFC's E\&S performance standards cover cardinal issues and areas not covered by prevailing Environmental Assessment (EA) process and practice, as well as GSR and CSR in the country, particularly as regards petroleum resources development industrial operations in the country. Nigeria is a country, where project-level EA, namely Environmental Impact Assessment (EIA), is still yet to advance considerably; ${ }^{1}$ thus the IFC's E\&S performance standards may help to improve environmental governance relating to EA of development projects and programmes in the country. These have potentials to improve government environmental regulatory mechanisms and institutions. Besides, the international benchmarked E\&S performance standards of the IFC would help to promote and enhance cumulative EA and strategic environmental assessment (SEA) practice in Nigeria. ${ }^{2}$ This is specifically so, in the context and framework of development projects such as the Nigeria LNG projects, which cumulatively cover seven trains (trains 1-7), even though SEA practice is not yet institutionalised in the country. This would boost business sustainability (exemplified by sustainability of operations of multinational oil and gas companies [MNOCs]), environmental protection and good environmental governance (GEG) ${ }^{3}$ in Nigeria, by promoting environmental and social performances of MNOCs operating in the country, towards environmentally-sound and sociallyequitable SD, particularly environmentally-sound and socially-equitable project finance partnership arrangements. Such partnership arrangements could be Public-Private partnerships involving government, the private sector and civil society groups, such as host communities, like mineral resources-rich communities of Nigeria, like the oil producing communities and areas of the Niger Delta region, ${ }^{4}$ in the form of the Canadian Whitehorse Mining Initiative (WMI). ${ }^{5}$ In this context, the IFC could in this context, be considered as mobilising finance for private sector operations, towards promoting and guaranteeing green economic growth and development in developing countries. ${ }^{6}$

With regard to energy and major natural resources development operations, such as EIOs, like petroleum resources development operations, the IFC's Public-Private partnership arrangements in Nigeria may have impact-benefit clauses and thereby also serve as multi-stakeholders Impact-Benefit Agreements (IBAs) in favour of the oil-rich communities of the Niger Delta region and other oil producing communities and areas of Nigeria. Furthermore, such Public-Private partnership arrangements consummated in the interest of oil producing as well as other major natural resources producing areas, such as other mineral resources-rich communities and areas in Nigeria may have Impact benefit clauses and thereby also serve as multi-stakeholders SD-oriented Good Neighbour Agreements (GNAs). Multi-stakeholders IBAs ${ }^{7}$ and other forms of SD-oriented GNAs, such as the Canadian Whitehorse Mining Initiative (WMI), ${ }^{8}$ Socio-economic and Cultural Heritage

${ }^{1}$ M. McCabe and B. Sadler (eds), Studies of EIA Practice in Developing Countries: A Supplement to the UNEP Training Resource Manual (The Economic and Trade Branch, Division of Technology, Industry and Economics [DTIE] UNEP 2002), 63-74.

${ }^{2}$ E. T. Bristol-Alagbariya (2013 [n25]), 33-49, 73-96, 276-285 and 289-293; B. Sadler et al (eds), Handbook of Strategic Environmental Assessment (Earthscan 2011); R. Therivel, Strategic Environmental Assessment in Action (Earthscan 2012); B. Dalal-Clayton and B. Sadler, Strategic Environmental Assessment: A Sourcebook and Reference Guide to International Experience (International Institute for Environment and Development Routledge 2005); H. Abaza et al, Environmental Impact Assessment and Strategic Environmental Assessment: Towards an Integrated Approach (UNEP 2004).

${ }^{3}$ A. Sapat (ed), Routledge Handbook of Environmental Governance (Routledge 2017); A. Vatn, Environmental Governance: Institutions, Policies and Actions (Edward Elgar Publishing 2015); J.P. Evans, Environmental Governance (Routledge 2012).

${ }^{4}$ E. T. Bristol-Alagbariya (2010 [n37]), 144-146.

5 Natural Resources Canada, 'Whitehorse Mining Initiative' <http:/www.nrcan.gc.ca/miningmaterials/policy/government-canada/8698 $>$ Accessed 27 April, 2020.

${ }^{6}$ IFC, Private Sector Development Solutions (IFC 2013 7[1]); IFC (World Bank Group), Mobilizing Public and Private Funds for Inclusive Green Growth Investment in Developing Countries: A Stocktaking Report Prepared for the G20 Development Working Group (IFC 2013), 48-88.

${ }^{7}$ A. J. Wright (The Canadian Community Economic Development Network [CCEDNet]), 'Impact and Benefit Agreements: The Role of Negotiated Agreements in the Creation of Collaborative Planning in Resource Development' $<$ https://ccednet-rcdec.ca/en/toolbox/impact-and-benefit-agreements-role-negotiated-agreements $>$ Accessed 27 March, 2020.

8 Natural Resources Canada, 'Whitehorse Mining Initiative' < http://www.nrcan.gc.ca/miningmaterials/policy/government-canada/8698> Accessed 27 April, 2020. 
Schemes, Community Development Trusts and Heritage Funds like the Alaska Permanent Fund ${ }^{1}$ have the potential of promoting SD in the interest of mining and mineral resources-rich communities and areas of Nigeria.

Using the IFC's E\&S performance standards as a basis to consummate SD-Oriented Good Neighbour Agreements (GNAs) in Nigeria, in favour of mining and mineral resources-rich communities and areas of the country, would underscore the relevance and vitality of these IFC's standards and the corporation's entire sustainability framework in Nigeria and other developing countries and emerging economies, with poor, marginalised and neglected major natural resources-rich communities. Doing so would make the IFC's sustainability framework contribute more to greater human wellbeing, Sustainable Community Development (SCD) and environmentally-sound, ecologically-centred and socio-economically equitable SD in developing countries and emerging economies. ${ }^{2}$ Consequently, by and large, the IFC could, in this context, be considered as mobilising finance for private sector operations, towards promoting and guaranteeing green economic development, growth and all-round prosperity, in emerging economies and developing countries like Nigeria (as part of the Planet Earth), ${ }^{3}$ in the course of the IFC's project financing and corporate financing schemes. ${ }^{4}$ In this and other ways, the IFC's Sustainability Framework, which the IFC's E\&S performance standards are part of, would be helping to contribute to GEG, GSR, CSR, and overall GG in Nigeria and other developing countries and emerging economies.

\title{
6. IFC: Project Financing, Corporate Financing and Modern Imperialistic Form of Financing of Development in Developing Countries
}

It is at this juncture imperative to take a glance at the subject-matters of project finance and corporate finance in relation to the IFC, due to our numerous references to the IFC's project financing and corporate financing schemes in developing countries and emerging economies. While proceeding to do so, we recall that the IFC was established for the purpose of engaging in private sector development, towards poverty reduction ${ }^{5}$ in developing countries, which we also consider as developing markets.

Firstly, project financing, which tailored to meet the needs of specific projects, simply means funding projects. It may be described as a loan that is primarily dependent on a project's cash flow (rather than the balance sheets of the project's sponsors) for purposes of the project's loan repayment, while the project's assets, rights and interests are held (by the provider[s] of the loan) as secondary collateral. ${ }^{6}$

One fundamental criterion for financing a project is whether the project is economically viable or not.

\begin{abstract}
${ }^{1}$ Alaska Permanent Fund Corporation (APFC), 'Investing for Alaska Investing for the Long Run: Our Mandate' $<$ https://apfc.org/> Accessed 7 February, 2020; D. Peel and N. Bailey, Celebrating Community Involvement (Development Trusts Association 2003), especially 3-15.

${ }^{2}$ R. Hannesson, Investing for Sustainability: The Management of Mineral Wealth (Kluwer 2001); L. BarreraHernandez et al (eds), Sharing the Costs and Benefits of Energy and Resources Activity: Legal Change and Impact on Communities (Oxford University Press 2016); E. T. Bristol-Alagbariya (2010 [n37]); D. N. Zillman et al (eds), Human Rights in Natural Resources Development: Public Participation in Sustainable Development of Mining and Energy Resources (International Bar Association [IBA]/Oxford University Press 2002); Omorogbe Y. and Ordor A. O. (eds), Ending Africa's Energy Deficit and the Law: Achieving Sustainable Energy for All (Oxford University Press, 2018).

${ }^{3}$ IFC, Private Sector Development Solutions (IFC World Bank Group [WBG] 2013 7[1]); IFC (World Bank Group), Mobilizing Public and Private Funds for Inclusive Green Growth Investment in Developing Countries: A Stocktaking Report Prepared for the G20 Development Working Group (n78).

${ }^{4}$ C. Tan and J. Faundez (eds), Natural Resources and Sustainable Development: International Economic Law Perspectives (Edward Elgar Publishing 2017); R. Perman et al, Natural Resource and Environmental Economics (Addison Wesley/Pearson Education 2011); T. Jackson, Prosperity without Growth: Economics for a Finite Planet (Earthscan 2011); T. Jackson, Prosperity without Growth?: The Transition to a Sustainable Economy (Sustainable Development Commission 2009); homepage of the Earth Charter Initiative (n24).
\end{abstract}

5 IFC, 'Where Principles Meet Practice: 4 Our Internal Standards and Operations' $<$ https://www.ifc.org/wps/wcm/connect/8e496523-5c7d-4025-bef38dd666c3c852/AR2010 Chapter4.pdf?MOD=AJPERES\&CVID=iYNkJIx $>$; WBG, 'Documents and Reports: Evaluation of IFC's Poverty Reduction Focus and Results (Approach Paper 82194)' $<$ http://documents.worldbank.org/curated/en/468421468340845016/pdf/821940IEGAppro00Box379862B00PU BLIC0.pdf $>\quad$; The World Bank Group, 'Understanding Poverty/Topics' $<$ https://www.worldbank.org/en/topic/poverty $>$ all Accessed 27 April, 2020.

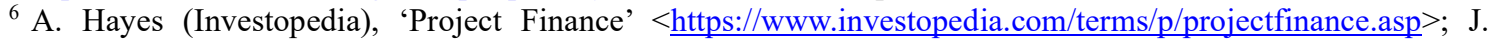
Kagan (Investopedia), 'Loan' < https://www.investopedia.com/contributors/53409/> both Accessed 27 April, 2020 . 
Financial and technical viability of projects are often considered by financial investors such as the IFC, before the investors accept to finance projects in developing countries. ${ }^{1}$ While investing to finance projects, the IFC identifies and addresses the risks associated with projects up-front and how to manage the project in order to finance it successfully. ${ }^{2}$ By so doing, the IFC has, in the course of its existence, been engaging in financing projects (project finance) as a tool for investment and economic development in developing countries and emerging economies.

There are two basic types of project finance, namely non-recourse project finance and limited-recourse project finance. ${ }^{3}$ Non-recourse project finance is an arrangement whereby lenders (creditors or investors) rely on money (cash flow) derived from the project financed (by a lender or lenders) for repayment of the fund (usually a loan facility) utilised to finance the project. On the other hand, limited-recourse project finance enables lenders to have alternative means of securing repayment, outside the project being financed, such as from a surety or even from an associated project or business operation. Nevertheless, from onset lenders who engage in financing a limited-recourse project still consider the economic viability of the project as a primary condition or fundamental basis for determining whether or not to finance such a project. The IFC is mainly engaged in financing limited-recourse projects in developing countries. ${ }^{4}$

Generally, the inability of the public sector (governments) of developing countries to perform their traditional responsibility of funding projects, which include public utility projects, such as infrastructural, healthcare, education, transport, sanitation and energy resources projects, gave rise to Public-Private sector partnership aimed at financing projects as well as privatisation schemes taking place in these developing countries. Projects are financed by such financial institutions as the IFC so as to boost economic growth and the advancement of developing countries. In return for financing projects, governments of developing countries often provide some incentives to encourage private sector financiers or investors. ${ }^{5}$

In the ongoing era of SD, alongside issues of financial and technical viability of projects, the IFC would as a project financial institution also ensure that a project is environmentally and socially feasible to sponsor. Hence, based on its sustainability framework and the framework's component environmental and social standards, the IFC would consider to finance a project in a developing country or an emerging economy, not only and merely because the project is able to generate financial returns, by way of servicing the funds committed to finance it. The IFC would also consider SD-oriented features of the project, and thereby examine environmental and social factors as aspects of the risk and sustainability features of a prospective project. By so considering environmental and social sustainability factors, features and issues of a project along with the economic viability of the project, the IFC is able to achieve its cardinal aims and objectives of operation. These aims and objectives are to alleviate poverty and thereby enhance public good or overall public good and SD, such as by establishing a sustainable business model of creating job opportunities and various other Impact-benefit opportunities for vulnerable people as reflected in its corporate culture, in the course of engaging in project financing and corporate financing in developing countries. ${ }^{6}$

Secondly, while considering corporate financing, it is significant to state from onset that it is the traditional form of financing, which means lending to finance a company, namely sponsoring a company financially, as distinct from financing a project. In other words, corporate financing involves financing companies, as different from project financing, which is associated with financing projects. Corporate financing is a form of financing, where the primary source of repaying financiers (investors, creditors or lenders) is from sponsoring a company, namely the operations of the company. It is an aspect of finance that deals with sources of funding firms, their capital structure, actions that their managers take to increase the value of the firms to their shareholders, as well as the tools and analysis used to allocate financial resources of the firms. Corporate finance departments of firms are normally charged with governing and overseeing financial activities and capital investment decisions of firms. Such decisions include whether to pursue a proposed investment and whether to

${ }^{1}$ IFC, 'IFC Insights: All Publications: Lessons of Experience No. 7: Project Finance in Developing Countries' $<$ https://www.ifc.org/wps/wcm/connect/publications_ext content/ifc_external_publication_site/publications listi ng page/lessonsofexperienceno7> Accessed 27 April, 2020.

${ }^{2}$ Ibid; The Wold Bank Group (WGB) (n11).

3 Ibid; K. Clark (Investopedia), Recourse Loans vs. Non-Recourse Loan: What's the Difference? $<$ https://www.investopedia.com/ask/answers/08/nonrecourse-loan-vs-recourse-loan.asp $>$ Accessed 27 April, 2020.

${ }^{4}$ IFC, 'IFC Insights: All Publications: Lessons of Experience No. 7: Project Finance in Developing Countries' (n87).

${ }^{5}$ Ibid.

${ }^{6}$ IFC, 'IFC Insights: IFC Sustainability Framework' (n41): J. Matthewman, ' The Bretton Woods Institutions and Development Partnerships' < https://www.e-ir.info/2012/02/08/the-bretton-woods-institutions-and-developmentpartnerships/> Accessed 27 April, 2020. 
pay for the investment with equity, debt or both. ${ }^{1}$ Consequently, in the context of corporate financing, if a project undertaken by the company being financed fails, lenders do not necessarily suffer, where the company being financed is financially viable. On the other hand, in project finance, if a project being financed fails, lenders would invariably incur losses. ${ }^{2}$

While engaging in corporate financing, the IFC provides financial assistance directly in the form of loans and equity to private enterprises in developing countries. ${ }^{3}$

On the whole, be it a case of corporate finance or that of project finance, which are basic aspects or divisions of finance, the IFC would consider its sustainability framework as a fundamental basis to decide whether or not to commit finance to sponsor a company or to sponsor a project. So, the IFC would normally give premium to its E\&S performance standards as aspects of its sustainability framework, in terms of engaging in corporate financing and project financing in emerging economies and developing countries. When the IFC takes into consideration its sustainability framework and the framework's accompanying E\&S sustainability standards, before engaging in corporate finance or project finance in a developing country or an emerging economy, the corporation helps to contribute to GEG, GSR, CSR and overall GG in these countries. ${ }^{4}$

Besides, we wish to embark on an exploratory examination of the vexed global politics of external financing of development in developing countries, from the background of the domestic roots of the imperialist nature of international indebtedness of these countries. ${ }^{5}$ May we therefore indicate out-rightly that a critical examination of the relationship between global capitalist finance, worldwide flows of capital in the form of money and modern imperialism in developing countries, in the context of the international and domestic roots of the controversial question of global debt crisis, is quite captivating and gratifying. This examination reveals that the IFC is one of the modern Bretton Woods institutions that have a traditional pattern of lending, which contributes to present-day imperialist international indebtedness of developing countries, ${ }^{6}$ which negatively impacts on the essence and basis of existence of these institutions ${ }^{7}$ and on SD. ${ }^{8}$ On this note, it may be recalled that the IFC, MIGA, IDA and ICSD are considered as four additional agencies of the WBG vis-à-vis the historic Bretton Woods' institutions, which were created between 1956 and $1988 .{ }^{9}$

\section{Conclusion}

This study gives a background of the IFC as one of the four agencies of the World Bank Group (WBG) $v i s-\grave{a}$-vis the historic Bretton Woods institutions established between 1956 and 1988. The other agencies of the Bank Group are the International Development Association (IDA), the Multilateral Investment Guarantee Agency (MIGA) and the International Centre for Settlement of Investment Disputes (ICSID). The study discusses the IFC as an international financial institution that offers investment, advisory and asset-management services to encourage private-sector development in less-developed countries.

\footnotetext{
${ }^{1}$ Will Kenton (Investopedia), 'Corporate Finance' < $\underline{\text { https://www.investopedia.com/terms/c/corporatefinance.asp }}>$ Accessed 27 April, 2020.

2 IFC, 'IFC Insights: All Publications: Lessons of Experience No. 7: Project Finance in Developing Countries' (n83).

3 IFC, Project Finance in Developing Countries: Number 7 Lessons of Experience IFC 1999$) 1$. $<$ https://elibrary.worldbank.org/doi/pdf/10.1596/0-8213-4434-X $>$ Accessed 27 April, 2020.

${ }^{4}$ IFC, 'IFC Insights: IFC Sustainability Framework' (n41).

${ }^{5}$ S. P. Riley (ed), The Politics of Global Debt (Palgrave Macmillan/St. Martin's Press 1993); J. Käkönen, 'The World Bank: A Bridgehead of Imperialism '[1975] 5 (3) Instant Research on Peace and Violence, 150-164.

${ }^{6}$ I. Alami, 'Global Finance Capital and Third World Debt' $[11$ May, 2019]The Palgrave Encyclopedia of

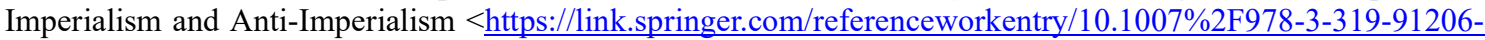
6 123-1> Accessed 27 April, 2020; G. Bird, 'Sisters in Economic Development: The Bretton Woods Institutions and Developing Countries' [1993] 5 (1) Journal of International Development, 1-25; D. Moore-Sieray, 'The Bretton Woods Institutions and the Self-Deceiving State in Africa: How International Finance Capital and Blunted Vision Have Underdeveloped Africa' [1997198] 27/28 Journal of African Research \& Development,
} 183-196.

7 A. Chowdhury and J. K. Sundaram, 'Bretton Woods Institutions: From Solution to Problem'

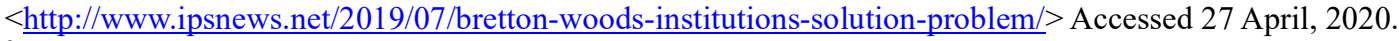

${ }^{8}$ UN Department of Economic and Social Affairs, World Economic and Social Survey 2013 Sustainable Development Challenges (UN 2013); W. Beckerman, A Poverty of Reason: Sustainable Development and Economic Growth (The Independent Institute 2002); T. Jackson, Prosperity without Growth: Economics for a Finite Planet (Earthscan 2011); T. Jackson, Prosperity without Growth?: The Transition to a Sustainable Economy (Sustainable Development Commission 2009).

${ }^{9}$ K. M. E. Dominguez (n22). 
The study examines the movement towards sustainability, namely the age-old concern and activity of how to achieve a more just, sustainable and peaceful world on the platform and strength of the wellbeing of humans and overall resources of nature, to enable the Earth thrive. It considers that sustainability may more concretely be viewed in relation to $\mathrm{SD}$, as evidenced by ongoing global efforts and trend toward $\mathrm{SD}$, which is pioneered and progressively being spearheaded by the UN. It thus features SD, embedded in the concept of sustainability, as the foundation for contemporary humanity's ongoing UN-led global framework for international cooperation and partnerships around the world. For instance, at the level of the UN, the Economic and Social Council (ECOSOC) brings people and issues together to promote collective action for a sustainable world. ECOSOC organises, through intergovernmental bodies, follow-up measures of major UN conferences and summits. The Council, which is a platform for fostering debate and innovative thinking, coordinates memberstates of the UN to translate internationally agreed goals into actual programmes in the member-states. Such agreed goals include SD initiatives of the UN system like those on international cooperation, collaboration and partnerships towards SD.

Consequently, the study discusses the IFC's approach to sustainability, which is governed by the corporation's sustainability framework and corporate governance methodology that are designed to help its clients and partners, such as intermediary financial institutions, to improve their performances, enhance transparency, engage with the people affected by the investments of the IFC, so as to protect the environment and achieve other development Impact-benefits. The IFC's sustainability framework is an integral part of the corporation's approach to risk management and its strategic commitment to SD. The IFC uses its sustainability framework along with its other strategies, policies and initiatives to direct its business activities, in order to achieve its overall development objectives. It highlights that the IFC considers business sustainability as being important and critical to the success of business (business organisations: companies).

The study thus examines the IFC's sustainability framework, which is one among other numerous examples of SD-oriented partnership mechanisms associated with the advancement of corporate responsibility (corporate social responsibility [CSR]), business sustainability and overall SD in developing countries. It discusses the IFC's sustainability framework and its peculiar policies and environmental and social (E\&S) performance standards, which are globally recognised international benchmarked soft law partnership mechanisms that are utilised to assess and manage E\&S risks of private sector (business) operations, such as the IFC's projects financing and corporate financing schemes. These standards help the IFC's clients and partners, some of which are financial intermediaries, to understand and manage the environmental, social and corporate governance (ESG) risks they face in developing countries and emerging economies. These standards are actualising the initiatives of the UN regarding generating SD-oriented cooperation, collaboration and partnerships, such as Private Sector Partnerships (PSPs) and Public-Private Sector Partnerships (PPSPs), in the course of the IFC's project financing and corporate financing schemes in developing countries, and thereby contributing to business sustainability and SD around the world. These standards widen the scope of as well as intensify E\&S performance obligations and commitment of IFC clients and partners, in order to sensitise, encourage, persuade, propel and/or even possibly compel them to properly and effectively execute the corporation's projects and corporate financing schemes in developing markets and emerging markets. They also engineer improvement of environmental protection, boost good environmental governance (GEG), advance CSR and enhance host governments social responsibility (GSR), towards the betterment of the welfare of citizens, generic human wellbeing, environmentally-sound and socio-economically equitable growth, prosperity and SD in developing countries.

Consequently, the study recommends that the implementation of the IFC's sustainability framework, particularly its component E\&S performance standards, should be strengthened, so as to make these standards contribute more to environmentally-sound, ecologically-centred and socio-economically equitable SD in developing countries, especially countries like Nigeria, which are plagued by bad governance and whose domestic environmental laws, GSR, corporate regulatory frameworks and their accompanying CSR systems fall short of the stipulations of the IFC's sustainability framework and the E\&S performance standards inherent in the framework.

Finally however, in the context and framework of the international and domestic roots of the controversial politics of global debt crisis, the study aligns with a critical examination of the relationship between global capitalist finance, worldwide flows of capital in the form of money and modern imperialism in developing countries, which reveals that the IFC is one of the modern Bretton Woods institutions that have a traditional pattern of lending, which contributes to present-day imperialist indebtedness of developing countries to the global north.

\section{References}

Abaza H., Bisset R. and Sadler B., Environmental Impact Assessment and Strategic Environmental Assessment: 
Towards an Integrated Approach (UNEP 2004).

Andiof J. S. Waddock B. Husted and S. S. Rahman (eds), Unfolding Stakeholder Thinking: Theory, Responsibility and Engagement (Routledge 2017).

Andiof J. S. Waddock B. Husted and S. S. Rahman (eds), Unfolding Stakeholder Thinking 2: Relationships, Communication, Reporting and Performance (Routledge 2017).

Barrera-Hernandez L., Barton B., Godden L., Lucas A., and Ronne A. (eds), Sharing the Costs and Benefits of Energy and Resources Activity: Legal Change and Impact on Communities (Oxford University Press 2016).

Bell S. and Morse S., Sustainability Indicators: Measuring the Immeasurable? (Earthscan 2008).

Bristol-Alagbariya E. T., 'The Concept, Principle, Law and Developmental Practice of Environmental Democracy towards Sustainable Development in Resources-rich Communities of Developing Countries: Focus on Nigeria's Oil Producing Delta Region' [2020] 94 Journal of Law, Policy and Globalization, 53, 62 and $69-70$.

Bristol-Alagbariya E. T., 'Duties Inherent in Permanent Sovereignty over Natural Wealth and Resources: A Case for Domestication of Benchmarked Regulatory Standards and Practices Governing Petroleum Development in Nigeria' (2019) 11 (1) Journal of Property Law and Contemporary Issues, 134, 138 and 152.

Bristol-Alagbariya E. T., 'Environmental Assessment Law and Practice in Nigeria towards Achieving the UN Sustainable Development Goals (UNSDGs) in the Country: Cases of SDGs 13 and 17' [2019] 92 Journal of Law, Policy and Globalization, 75-76.

Bristol-Alagbariya E. T., Governance Towards Sustainable Development in Nigeria: The Role of Strategic Assessment of Decisions \& Actions (Centre for Energy, Petroleum \& Mineral Law \& Policy [CEPMLP]/Dundee University Press [DUP] 2013) 33-35.

Bristol-Alagbariya E. T., Participation in Petroleum Development: Towards Sustainable Community Development in the Niger Delta (CEPMLP/DUP 2010), 83-101 and 144-146.

Bristol-Alagbariya E. T., 'Permanent Sovereignty over Natural Wealth and Resources: Literature Review, Benchmarked Soft Law Standards and Practices towards Sustainable Petroleum Development in the Niger Delta' (2019) 4 (2) University of Port Harcourt Journal of Private Law, 147, 149, 160 and 171.

Bristol-Alagbariya E. T, 'Sustainable Development: A Soft Law Concept Transforming SD-Oriented Initiatives of the UN System into Hard Law Instruments in UN Member-states and Promoting Partnerships around the Globe [2020] 94 Journal of Law, Policy and Globalization, 40-52.

Bristol-Alagbariya E. T., 'The UN Global Compact as a Soft Law Business Regulatory Mechanism Advancing Corporate Responsibility towards Business Sustainability and Sustainable Development Worldwide' [2020] 94 Journal of Law, Policy and Globalization, 27-39.

Bristol-Alagbariya E. T., 'Theories and the Legal Principle of Permanent Sovereignty over Natural Wealth and Resources in Relation to Petroleum Development in Nigeria' [2019] 4 (2) University of Port Harcourt Journal of Private Law, 204-206.

Dresner S., The Principles of Sustainability (Earthscan 2008).

International Finance Corporation (IFC) (World Bank Group), Mobilizing Public and Private Funds for Inclusive Green Growth Investment in Developing Countries: A Stocktaking Report Prepared for the G20 Development Working Group (IFC 2013), 48-88.

Ladan M. T., Sustainable Development Goals, Climate Change and Extractive Resource Management in Africa (Ahmadu Bello University Press 2017).

Lindahl K. B., Baker S., Rist L. and A. Zachrisson, 'Theorising Pathways to Sustainability' [2016] 23 (5) International Journal of Sustainable Development \& World Ecology, 399-411.

McCabe M. and Sadler B. (eds), Studies of EIA Practice in Developing Countries: A Supplement to the UNEP Training Resource Manual (The Economic and Trade Branch, Division of Technology, Industry and Economics [DTIE] UNEP 2002), 63-74.

Olawuyi D. S., Extractives Industry Law in Africa (Springer Nature Switzerland AG 2018).

Omeje K. (ed), Extractive Economies and Conflicts in the Global South: Multi-Regional Perspectives on Rentier Politics (Ashgate Publishing 2008).

Omeje K., High Stakes and Stakeholders: Oil Conflict and Security in Nigeria (Routledge 2016).

Omorogbe Y. and Ordor A. O. (eds), Ending Africa's Energy Deficit and the Law: Achieving Sustainable Energy for All (Oxford University Press, 2018).

Perman R., Ma Y., Common M., Maddison D. and Mcgilvray J., Natural Resource and Environmental Economics (Addison Wesley/Pearson Education 2011).

Sadler B., Aschemann R., Dusik T., Fischer T., Partidario M. and Verheem R. (eds), Handbook of Strategic Environmental Assessment (Earthscan 2011).

Sapat A. (ed), Routledge Handbook of Environmental Governance (Routledge 2017). 
Skjærseth J. B., Stokke O. S. and Wettestad J., 'Soft Law, Hard Law, and Effective Implementation of International Environmental Norms’ [2006] 6 (3), Global Environmental Politics, 104-120.

Therivel R., Strategic Environmental Assessment in Action (Earthscan 2012).

UN Department of Economic and Social Affairs, Office for ECOSOC Support and Coordination, Achieving Sustainable Development and Promoting Development Cooperation: Dialogues at the Economic and Social Council (UN 2008).

The UN Department on Economic and Social Affairs (UNDESA), Indicators of Sustainable Development: Guidelines and Methodologies (UN 2007).

Zillman D. N., Lucas A. R. and Pring G (R.) (eds), Human Rights in Natural Resources Development: Public Participation in Sustainable Development of Mining and Energy Resources (Oxford University Press 2002) (Oxford University Press 2002). 